\section{EL SIMBOLISMO DEL JABALÍ EN EL ÁMBITO CELTA PENINSULAR}

\author{
THE SYMBOLISM OF THE BOAR IN THE \\ CELTIC PENINSULAR AREA
}

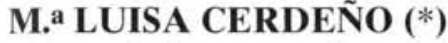 \\ EMILIO CABANES (*)
}

\section{RESUMEN}

Se subraya la existencia de numerosas representaciones de jabalí, mayoritariamente fíbulas zoomorfas, en la Meseta Occidental, territorio en el que se habló una lengua celta. Se apuntan las posibles similitudes con el mundo celta europeo donde el jabalí jugó un papel destacado y cuyas representaciones fueron igualmente abundantes.

\begin{abstract}
This paper highlights the existence of several representations of wild boar primarily on zoomorphic fibulae, in the Western Meseta, which was a Celtic language speaking area. We point out the possible relationship with the European Celtic world, where the boar played an important role and where many boar figurines have been found.
\end{abstract}

Palabras clave: Simbolismo animal. Jabalí. Celtas Península Ibérica.

Key words: Animal Symbolism. Boar. Celtic Iberian Peninsula.

(*) Departamento de Prehistoria. Facultad de Geografía e Historia. Universidad Complutense. 28040 Madrid. El artículo fue remitido en su versión final el 11-I-94.

\section{INTRODUCCIÓN}

Las representaciones animalísticas de los pueblos antiguos siempre han suscitado la atención de los investigadores puesto que, al ser consideradas exponentes de ciertos valores rituales o símbolos de determinadas creencias, su estudio podía proporcionar información sobre aspectos menos tangibles de la actividad social. Aunque no siempre estas interpretaciones son necesariamente acertadas, es evidente que las figurillas zoomorfas fueron fabricadas y utilizadas con una determinada finalidad.

La existencia de numerosas imágenes de jabalí en la España prerromana, especialmente en el ámbito de la Meseta Occidental, nos parece interesante tanto por la interpretación que de ellas podamos hacer como por constituir un elemento más que parece avalar las relaciones que tiertas zonas peninsulares mantuvieron con $\mathrm{Eu}$ ropa continental, si tenemos en cuenta que la caza del jabalí, así como la cría de cerdos ha estado tradicionalmente asociada al mundo de los Celtas (Green, 1992: 17) quienes lo incluyeron entre sus animales sagrados, junto al caballo o al toro. La coincidencia del territorio peninsular aludido con las regiones en las que se hablaron las lenguas celtíbera y lusitana, al menos la primera considerada indiscutiblemente celta, no deja de resultar significativa a este respecto.

La caza del jabalí, por ser éste una especie salvaje prolífica y típica de zonas boscosas, constituyó una práctica común entre dichos pueblos y es posible que esta actividad conlle- 
vase cierta carga simbólica y la necesidad de determinados rituales, no tanto porque el jabalí sea un animal especialmente agresivo, sino porque su captura con sólo armas arrojadizas debía ser difícil dada su gruesa piel, que haría necesaria una gran destreza o su persecución después del primer tiro, momento en que ya sí se revuelve con fiereza contra sus perseguidores. Su condición de animal nocturno, así como su manera de obtener el alimento rebuscando bajo tierra, debieron contribuir a conferir a esta especie un peculiar significado.

Las representaciones de jabalí que han llamado nuestra atención son de diversos tipos, desde pequeñas figurillas de bronce hasta las grandes esculturas de piedra y aunque es seguro que existieron diferencias de concepto entre unas y otras, pensamos que debieron ser consideradas por la sociedad que las fabricó como símbolos, entendiendo como tales «las imágenes o figuras con que se representa un concepto moral e intelectual, por alguna semejanza entre ese concepto y dicha imagen", según definición del diccionario de la Real Academia.

Esta utilización de símbolos no sólo es exclusiva de pueblos primitivos, sino que puede observarse hasta nuestros días en cualquier sociedad, pues si aceptamos la idea del profesor Aranguren (1992: 256), «el hombre es animal simbólico: entiende el mundo, opera sobre él, lo transforma y se comporta siempre a través de símbolos. Los símbolos son imágenes investidas de sentido y no cristalizadas, sino plásticas, cambiantes, vivas. Los símbolos se articulan en sistemas y se colectivizan en los mitos».

El simbolismo, pues, ha sido uno de los temas que ha interesado siempre a los antropólogos, habiéndose contemplado su estudio a través de distintos planteamientos teóricos, desde la visión estructuralista de considerar la cultura como un sistema de símbolos compartidos, hasta las matizaciones apuntadas por la Antrología Cognitiva (Sperber, 1978).

\section{LAS REPRESENTACIONES DE JA- BALÍ EN EL TERRITORIO MESE- TEÑO}

Las figuraciones de esta especie que más llamaron nuestra atención fueron las que procedían de diferentes yacimientos de época prerromana de la Meseta, puesto que vienen siendo nuestro objeto de estudio en los últimos años, y sobre su origen e interpretación tratan estas líneas. Ello no impide que recordemos también, la existencia de figuras de jabalí en otros ámbitos geográficos de la Península, aunque su presencia no es tan significativa y sus vinculaciones culturales creemos que son diferentes.

Como puede verse en la figura 1, el jabalí fue representado de numerosas formas y sobre distintos objetos, que hemos agrupado en seis apartados diferentes:

1) Fíbulas zoomorfas. 2) Broches de cinturón. 3) Figurillas diversas, entre las que se pueden distinguir algunas variantes. 4) Téseras de hospitalidad. 5) Estelas de piedra. 6) Verracos, grupo muy abundante formando un conjunto de características especiales.

No es nuestro objetivo hacer un exhaustivo estudio tipológico de cada uno de estos grupos de objetos, pero hemos procedido a una ordenación general de los ejemplares conocidos por una mera cuestión de orden y para comprobar si los distintos modelos responden a una premeditada idea que se hubiera ido suscediendo a lo largo del tiempo, sobre todo si aceptamos el presupuesto de que en cualquier objeto «la forma no resulta escogida al azar, sino que es el resultado de una tradición estética y de una funcionalidad, entre otros factores» (Chapa, 1984: 253).

\section{1) Fíbulas zoomorfas}

La mayoría de las representaciones de jabalí que se conservan en la Meseta corresponden a fíbulas de bronce, de las que hemos recopilado 55 , sin contar otros ejemplos zoomorfos en los que es muy problemático identificar la especie.

Desde el punto de vista tipológico, siempre se ha considerado que el conjunto de las fíbulas zoomorfas se incluye en el grupo denominado de La Tène, cuya característica más relevante es que el pie se prolonga excesivamente hasta terminar uniéndose y fusionándose con el puente que, en este caso, ha sido sustituido por la figura de un animal. El resorte de estas fíbulas es bilateral, soportado por un eje que atravesaría el orificio que casi todos los ejemplares conservan en la cabecera del puente, es decir, en la zona inferior de las patas traseras del animal representado. Según Argente (1986-87: 155), la evolución de las fíbulas zoomorfas se iniciaría al final del período La Tène I y llegaría a su pleni-

T. P., $51, \mathrm{n}^{\circ} 2,1994$ 
tud en La Tène II, centrándose, por tanto, en los siglos IV y sobre todo III a.C.

El aspecto estilístico mas diferenciador de nuestras fíbulas es la forma de representar el cuerpo del jabalí y en este dato nos hemos basado para hacer una somera agrupación de tipos en los que también se constatan otros atributos

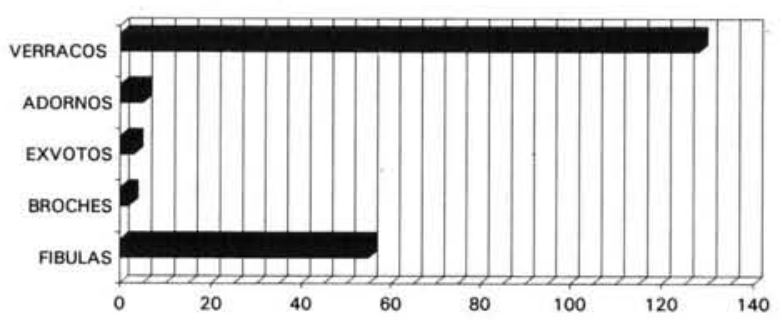

Fig. 1. Gráfico de las diferentes formas de representación de jabalí en el área céltica meseteña.

importantes. No todos los ejemplares que hemos revisado cumplen estrictamente los cánones tipológicos antes definidos, pues existen algunos en los grupos I y II cuyo pie no llega a

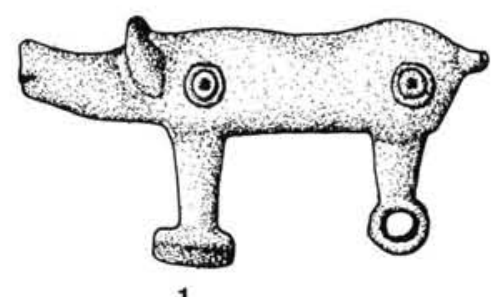

1
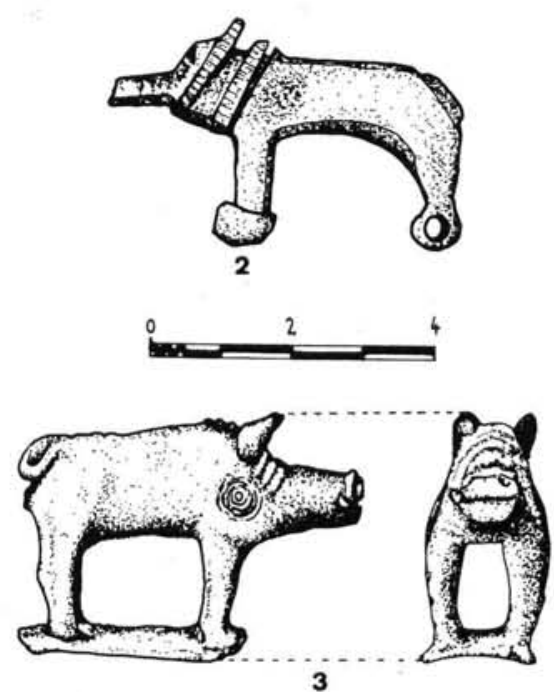

Fig. 2. 1 y 2: Fíbulas zoomorfas del grupo I, procedentes de Clunia y de la Meseta Occidental. 3: Exvoto de bronce procedente del valle del Duero (dibujos de J.P. Benito, sobre publicación autores). prolongarse $\mathrm{y}$, por tanto, no alcanza a fusionarse con el morro del animal (Figs. 2 y 3). Podríamos interpretar esta característica, en términos esencialmente tecnocronológicos, como signo de mayor antigüedad ya que la progresiva elevación del pie se considera sucesiva en el tiempo.

I) Representación naturalista del animal; el pie no se prolonga. Constituye el $13 \%$ del total de las fíbulas revisadas. Identificamos siete ejemplares: Clunia (Álvarez, 1991), Palencia o León, Palencia (Álvarez Ossorio, 1941), Meseta Occidental (Morán, 1938), El Berrueco (Salamanca) (Morán, 1924), Almaluez (Soria) (Domínguez, 1982) y Arcóbriga (Zaragoza) (Aguilera y Gamboa, 1916) (Fig. 2).

II) Representación naturalista del cuerpo del animal, pero cabeza estilizada, identificada por un hocico alargado que se eleva a modo de trompa y acaba constituyendo el rasgo más distintivo. En este grupo, con ventiuna piezas que representan el $38 \%$, pueden independizarse algunas variantes:

a) Hocico poco elevado. En los pocos casos conocidos, el pie no se prolonga. Incluimos tres ejemplares: Paredes de Nava (Palencia) (Moure, 1981), Valladolid (Wattemberg, 1959) e Iruña (Álava) (Caprile, 1986) (Fig. 3, 1 y 2).

b) Hocico poco elevado y patas delanteras prolongadas, sin llegar a tocar el puente. Estas extremidades están rematadas por una cabecita humana. Incorporamos seis: tres de Palencia (Álvarez Ossorio, 1941), una de Burgos (Wattemberg, 1959) y dos de la Meseta Occidental (Schüle, 1969; Benoit, 1954) (Fig. 3, 3-4-5).

c) Hocico alargado y levantado hacia arriba a modo de trompa. Las patas delanteras llegan a tocar el puente y, bien entre ellas, bien en el extremo del hocico, suele aparecer una cabecita humana. Proceden de: una de Paredes de Nava (Moure, 1981), dos de Palencia o León (Álvarez Ossorio, 1941), Rauda (Burgos) (Sacristán, 1986), dos de la Meseta Occidental (Wattemberg, 1959; Cerdeño, 1986), una de Iruña (Caprile, 1986) (Fig. 4). Algunas de ellas podrían considerarse tipos intermedios, por ejemplo, las dos procedentes de Palencia, en las que el pie se fusiona con el puente pero el hocico no es muy largo, y la procedente de Iruña que, por el contrario, posee un hocico muy levantado y el pie no se prolonga.

Estos modelos son los que algunos autores definieron como elefantes, pero creemos que debe descartarse tal hipótesis tanto por la cla- 

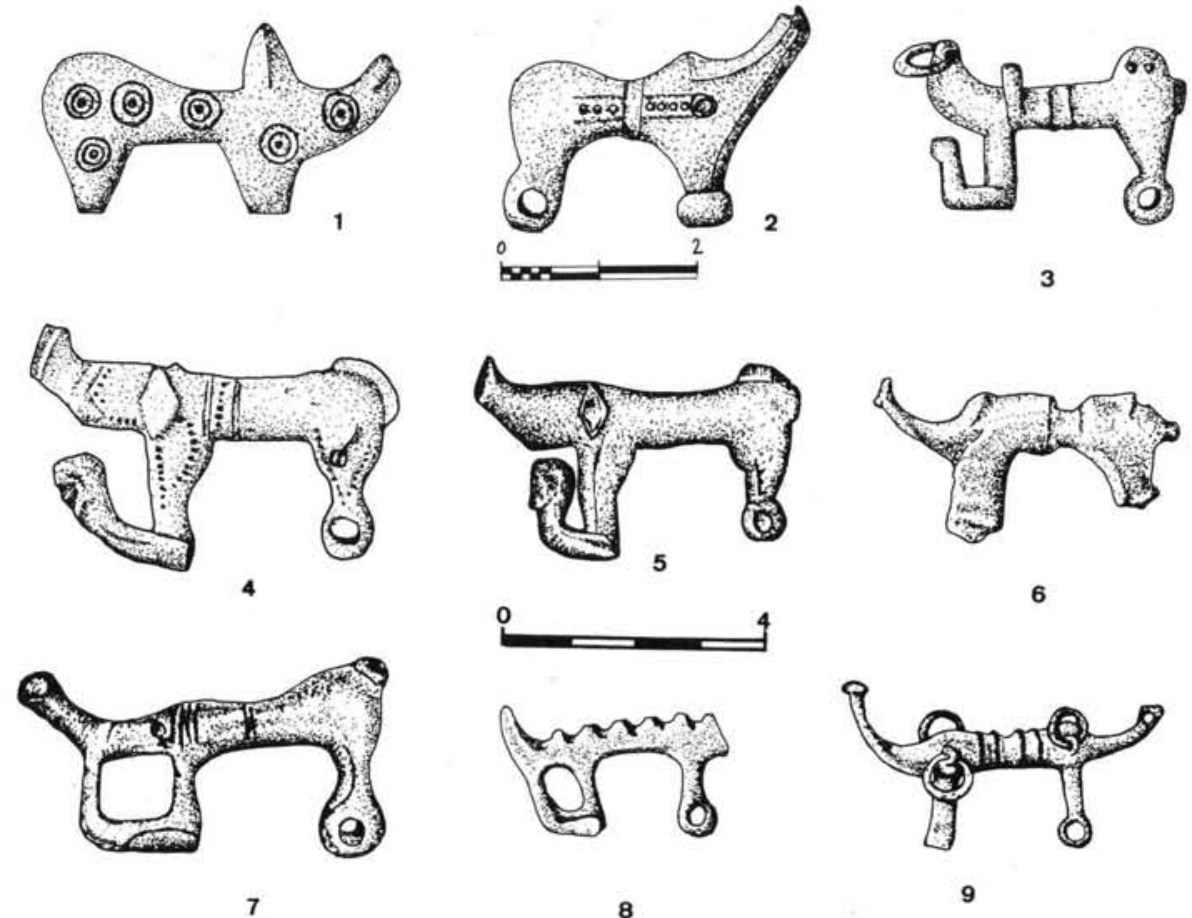

Fig. 3. 1 y 2: Fíbulas del grupo IIa: Valladolid e Iruña. 3, 4, 5: Fíbulas del grupo IIb: Burgos y Meseta Occidental. 6, 7, 8, 9: Fíbulas del grupo IId: Paredes de Nava y Valle del Duero (dibujos de J.P. Benito sobre publicación autores).
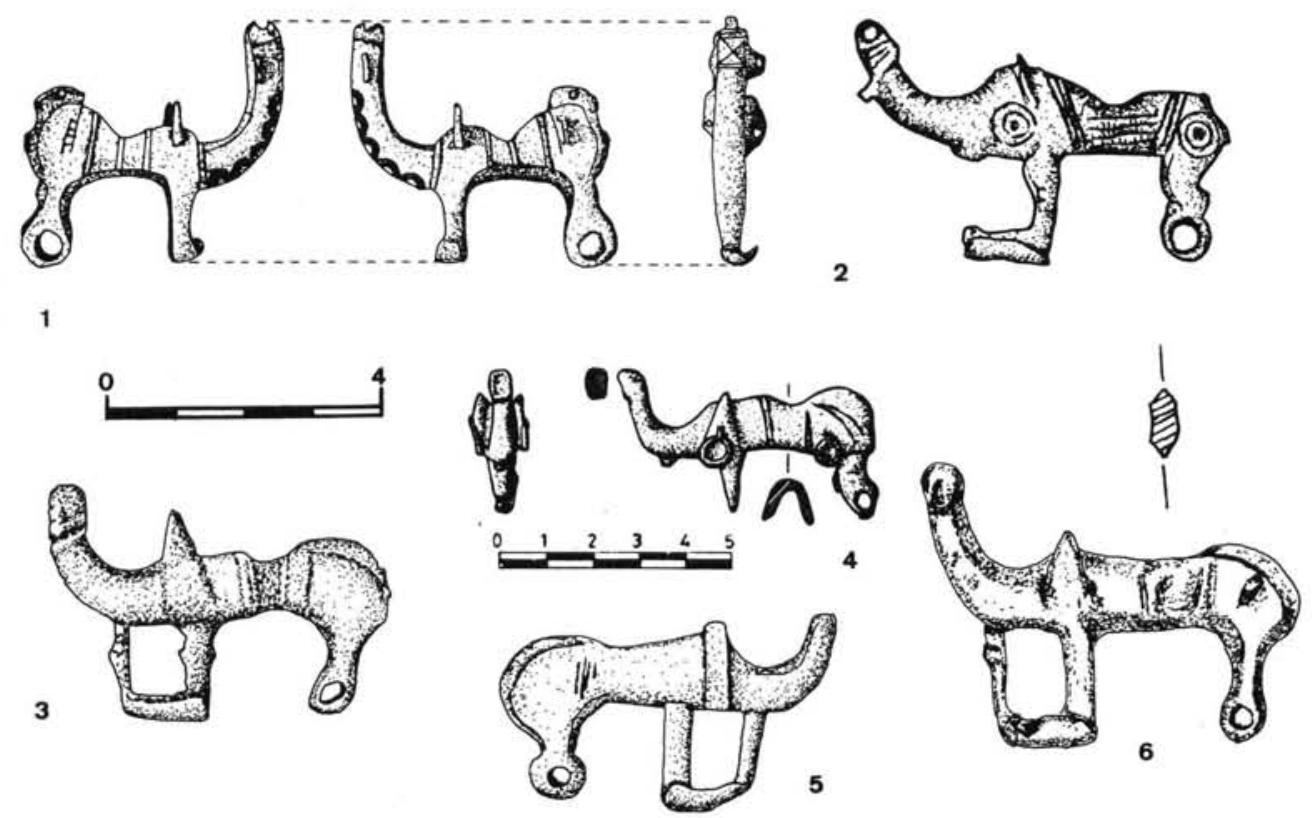

Fig. 4. Fíbulas de jabalí del grupo IIc. 1: Iruña. 2, 3, 5, 6: Meseta Occidental (dibujos J.P. Benito sobre publicación autores). 4: Roa (Burgos), según Sacristán.

T. P., $51, \mathrm{n}^{\circ} 2,1994$ 
ridad de los demás rasgos estilísticos de la figura, como porque estas comunidades indígenas sólo podrían haber visto paquidermos en época de Aníbal y no resulta coherente que los incorporaran tan rápidamente a su tradicional repertorio iconográfico. Debemos recordar, además, que en el lenguaje de los cazadores se denomina siempre trompa al hocico del jabalí por ser una parte muy potente de su cuerpo y su único medio de voltear la tierra u otros elementos para rebuscar en ellos los alimentos.

d) Tendencia general a la estilización de toda la figura del animal pero conservando el hocico levantado. Proceden de: Paredes de Nava (Moure, 1981), Calzadilla (Palencia) (Schüle, 1969), dos de la Meseta Occidental (Schüle, 1969) y Numancia (Argente, 1986-87) (Fig. 3, 6-9).

III) Representación esquemática del cuerpo, del que penden una serie de anillas; constituye el $25 \%$. A pesar de su esquematismo, consideramos que estas representaciones son figuras de jabalí porque la prolongación de las patas delanteras, hasta formar el propio hocico, parece sintetizar lo más distintivo de la especie. Incluimos catorce fíbulas: dos de Paredes de Nava (Moure y Ortega, 1981), tres de Palen- cia o León (Álvarez Ossorio, 1941), cuatro de Lancia (León) (Luengo, 1933-35), dos de la Meseta occidental (Schüle, 1969; Cerdeño, 1986), Miraveche (Burgos) (Wattemberg, 1959), Numancia (Schüle, 1969) y Valdenovillos (Guadalajara) (Aguilera y Gamboa, 1916) (Fig. 5).

IV) Representaciones zoomorfas muy esquematizadas que debemos calificar de dudosas puesto que es más problemático identificar la especie; representan el $24 \%$. Sin embargo, el apéndice caudal elevado y curvo, a modo de trompa, podría sugerir la representación del hocico del jabalí. Los trece ejemplares proceden de: nueve de Palencia o León (Álvarez Ossorio, 1941), Paredes de Nava (Moure, 1981), Lancia (Luengo, 1933-35), Meseta Occidental y Numancia (Schüle, 1969). No incluimos otras fíbulas zoomorfas, por ejemplo las cuatro procedentes de Palencia reproducidas en el mencionado catálogo de Álvarez Ossorio, en las que se encuentran muy diluidos los atributos más típicos.

Aparte del valor simbólico que pudiera tener la figura del propio jabalí, queremos destacar también la existencia de cabecitas humanas sobre algunas de las piezas del grupo II, bien entre la prolongación de las patas delanteras, bien en el extremo del hocico elevado (Figs. 4 y 5$)$.
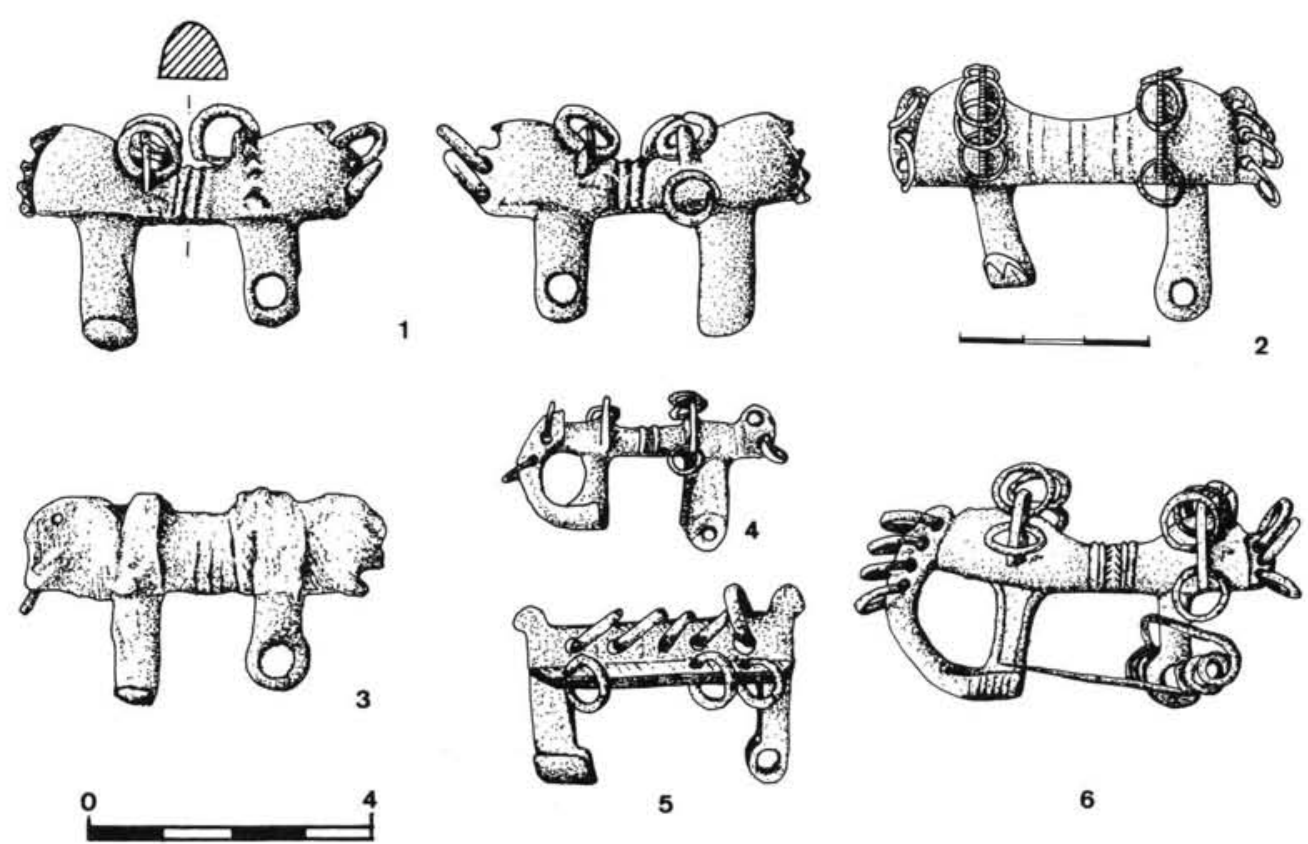

Fig. 5. Fíbulas zoomorfas de jabalí del grupo III. 1: Paredes de Nava. 2: Lancia. 3 y 5: Valle del Duero. 4: Valdenovillos (Guadalajara). 6: Miraveche (dibujos J.P. Benito sobre publicación autores). 


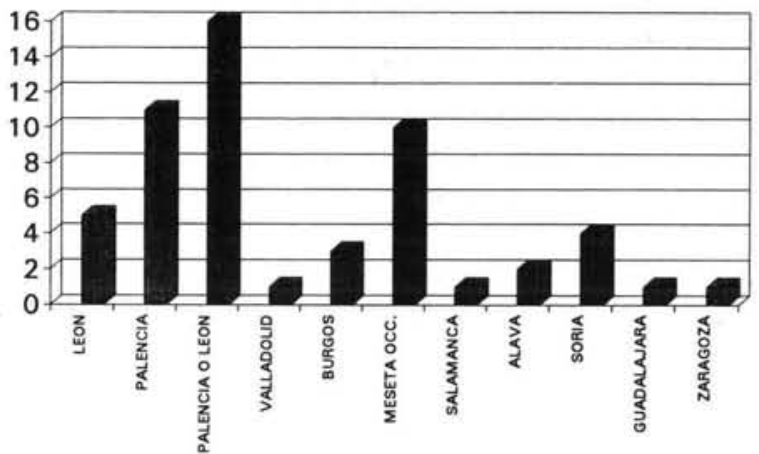

Fig. 6. Relación numérica de la distribución por provincias de las fíbulas zoomorfas de jabalí.

Coincidimos con la propuesta de Almagro y Lorrio (1992: 435) de considerar de prestigio las piezas con cabecita por su gran valor ideológico en relación con la costumbre, típicamente celta, de exponer la cabeza cortada del enemigo como trofeo. Tanto por los textos clásicos que hacen referencia a este ritual, como por las representaciones conservadas se acepta que en el mundo céltico se cortaba la cabeza del enemigo caído y se la sujetaba al caballo; más tarde, los cráneos eran colgados en las casas y, si eran ilustres, se las guardaba en una caja (Sopeña, 1987: 99 y ss.). Aunque en el ámbito celtibérico no se conservan demasiados documentos plásticos y literarios, creemos que las fíbulas de caballito y las de jabalí pueden ser un buen ejemplo.

Otro de los datos reseñables es su distribución geográfica pues, como vemos en el gráfico de la figura 6, ocupa casi toda la Meseta Occidental. Básicamente es el territorio ocupado por los vacceos algunas de cuyas poblaciones importantes fueron, precisamente, Pallantia, Intercantia (Villalpando), Rauda (Roa) o Arbocala (Toro).

\section{2) Broches de cinturón}

Existen, al menos, dos piezas hembras de broches de cinturón de tipo ibérico sobre las que aparecen grabadas figuras de jabalí.

- La primera de ellas procede de la sepultura 60 de la necrópolis de Miraveche (Burgos) (Fig. 7, 2) cuya decoración de finas líneas de puntos impresos rodea los bordes laterales y el vano central y forma una cenefa curva bajo los clavos de la base; entre dicha cenefa y el vano central está dibujada una figura de jabalí con el cuerpo bien proporcionado y la cabeza según el típico esquema de nuestro grupo II. Se conserva también la parte macho completa, decorada con líneas de puntos formando en el centro una estrella de cuatro puntas dobladas.

- El segundo ejemplar procede de un lugar indeterminado de la provincia de Toledo (Cabré, 1937: lám. XXIV) (Fig. 7, 2). Sobre la fina lámina de plata que lo cubre se han repujado una serie de volutas y, en el espacio entre el segundo y tercer vano, dos figuritas muy esquemáticas de jabalí, siguiendo el esquema observado en las fíbulas del grupo II.

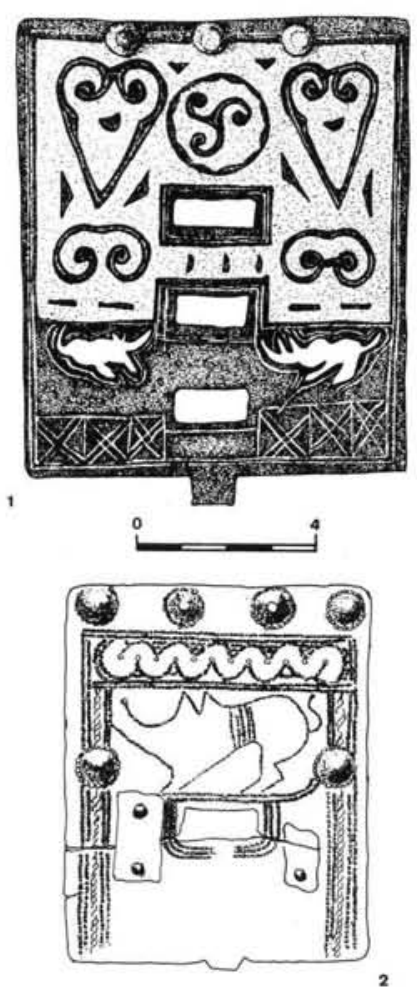

Fig. 7. Broches de cinturón con representaciones de jabalí: 1: Provincia de Toledo. 2: Miraveche (dibujos J.P. Benito, sobre publicación autores).

Se viene aceptando el origen y desarrollo de estos broches en el mundo ibérico y ya Cabré (1928 y 1937) los denominó de «tipo andaluz». Su presencia en el territorio meseteño (Soria, Guadalajara, Burgos, Ávila) puede interpretarse como producto de la influencia que esta cultura ejerció sobre las poblaciones del interior.

La mayoría de los ejemplares conocidos procede de necrópolis de incineración, donde formaban parte de los ajuares funerarios que en 
muchas ocasiones, como la del broche de Miraveche, eran los más ricos del yacimiento. Esta circunstancia nos ha llevado a pensar si las relaciones comerciales que existieron entre las gentes de la costa y las del interior podrían haber incluido la importación de objetos lujo, o bien haber estimulado su imitación, precisamente por no ser los que de forma habitual se utilizaban en la zona (Cerdeño y García Huerta, 1990: 91). Sin embargo, el motivo del jabalí sólo aparece en los dos ejemplares de la Meseta y ello parece confirmar que se trata de una aportación típicamente local y que en estas regiones fue donde dicho animal tuvo mayores connotaciones simbólicas.

Por su aparición en santuarios y necrópolis y sobre todo por su rica ornamentación, incluyendo el motivo de un jabalí, se puede pensar que tuvieron alguna significación, aparte de la mera función utilitaria. Algunos autores (Morán, 1975: 595-604) ya opinaron que los motivos decorativos parecen rebasar el puro carácter ornamental para convertirse en verdaderos amuletos. El propio Cabré (1937: 115) interpretó la figurita de jabalí que ahora mencionamos como una muestra más del culto totémico o mágico que aquellos pueblos tributarían a esta especie.

\section{3) Figuritas varias}

Existen otras figuritas de jabalí, bien solas, bien formando parte de la decoración de otros objetos, con algunas variaciones entre sí:

a) Figuritas de bronce aisladas que podrían considerarse exvotos, aunque no sabemos si pudieron formar parte de un conjunto de mayor entidad. Una procede de un lugar incierto de la Meseta Occidental (Fig. 2, 3), conservada en el Instituto Valencia de Don Juan y otras dos proceden de la provincia de Palencia o León, conservándose en las antiguas colecciones del Museo Arqueológico Nacional. Fueron conocidas por los antiguos investigadores que ya comentaron su visible parecido con los verracos o «cerdos de Ávila» (Paris, 1904: 204).

Un cuarto ejemplar podría ser la pesa de bronce macizo en forma de jabalí, procedente de Azaila y conservada en el Museo Arqueológico Nacional (Blánquez y Álvaro, 1983), aunque creemos que su cronología es ya romana. También nos parece de cronología tardía la figurita de bronce denominada el «Jinete de $\mathrm{Pa}$ lencia» publicada por P. Paris (1904: 223, 233 y lám. VI) que la interpretaba como encarnación de un dios de la caza.

b) Figuritas de jabalí como motivo ornamental de otras piezas mayores. Los ejemplos más conocidos son los remates calados encontrados en dos sepulturas de la necrópolis de Miraveche (Schüle, 1969: láms. 146 y 151) y la cabeza incompleta de otro animal. En la sepultura 80 de la misma necrópolis (Schüle, 1969: lám. 152) apareció una espada de hierro cuyo gavilán conservado está rematado por una cabeza animal de bronce, atribuible a un cerdo por su hocico achatado (Fig. 8).

Un adorno, aunque de diferente naturaleza, es la lúnula de plata del tesoro de Châo do Lamas (Coimbra, Portugal), con decoración repujada en la que aparecen cuatro cerdos o jabalíes, todos ellos vinculables al mundo religioso y funerario (Marco Simón, 1991).

c) Incluimos en este apartado dos figuritas fabricadas en arcilla y de peor ejecución que las de bronce. La primera de ellas procede de Numancia y aunque tiene un ligero reborde sobre la línea de lomo, como las cerdas de un jabalí,

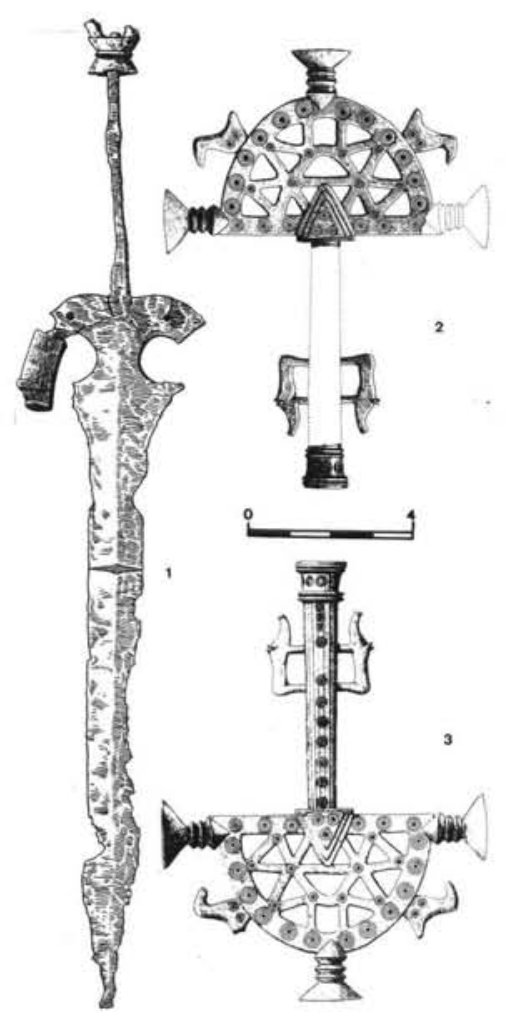

Fig. 8. Espada y remates, con adornos de cerdo y jabalíes, procedentes de la necrópolis de Miraveche, según Schüle (1969). 
podría tratarse de un cerdo ya que el hocico es achatado y toda la figura corta y redondeada. La segunda figurita procede del castro de Las Arribillas (Guadalajara) y, aunque muy incompleta, se considera un jabalí por tener destacado el pelaje de la línea del lomo (Galán, 1989-90: 181).

\section{4) Téseras de hospitalidad}

Algunas téseras de hospitalidad que tienen forma de jabalí son prueba de la pervivencia que siguió teniendo la representación de esta especie hasta momentos avanzados, ya en contacto con el mundo romano. Existen téseras con inscripciones en alfabeto ibérico y lengua celtibérica y otras en las que las inscripciones son ya latinas (Tovar, 1948: 78).

Estas piezas confirman la existencia del hospitium como institución social entre los pueblos prerromanos meseteños de carácter hispanocelta. Es una antigua costumbre que delimita los derechos y deberes de quienes acuerdan la hospitalidad. Pueden ser también una muestra del sistema gentilicio de aquellas sociedades, cuyas relaciones descansaban sobre la base del parentesco. Sin embargo, la aparición, tanto en las téseras como en otros textos epigráficos, del nombre de la ciudad o lugar de procedencia como nombre principal parece indicar que la organización jurídico-territorial en torno a ciudades o castros llegó a tener mayor importancia institucional que las organizaciones familiares (Fatas, 1991: 54).

\section{5) Relieves y grabados en piedra}

Se conocen algunas estelas de piedra, con inscripciones latinas, en las que vuelve a aparecer el motivo de la caza del jabalí. La más representativa podría ser la procedente de Lara de los Infantes (Burgos), con jinete armado, ayudado por otro personaje a pie, persiguiendo un jabalí (Osaba, 1955). Al igual que en otros ejemplos, la escena está acompañada por una serie de signos, motivos en ángulo recto, etc., de carácter astral en relación con la consideración del dominio celeste como residencia de las almas (Sopeña, 1987: 123).

Mencionamos también en este apartado una de las insculturas de la muralla del castro de Yecla de Yeltes en la que aparece una escena de caza en la que dos jinetes persiguen a dos supuestos jabalíes. Martín Valls (1983: 223 y 231) relaciona estos grabados, técnica y estilísticamente, con los petroglifos gallegos, fechándolos a partir del conjunto arqueológico del castro, que se ocupó desde la segunda Edad del Hierro hasta época romana y medieval.

\section{6) Los verracos}

Las figuraciones más conocidas de cerdo o jabalí de la España prerromana posiblemente sean las grandes esculturas de piedra denominadas verracos, nombre quizás impropio, ya que no todas representan a un «macho porcino reproductor». Por conservarse en la mayoría de los casos al aire libre han sido citadas en la bibliografía desde hace varios siglos, conociéndose alguna descripción de ellas del siglo XVI (Hernández, 1982: 211).

Desde entonces, los intentos de interpretación se han multiplicado existiendo multitud de opiniones al respecto. Entre los últimos trabajos, destaca el de López Monteagudo (1989) que defiende su carácter funerario, basándose en su vinculación a necrópolis o a lugares sagrados y también en la naturaleza de las inscripciones latinas que algunos ejemplares llevan grabadas. Por su parte, Álvarez Sanchís (1990: 277 y ss.) observa que sólo un pequeño porcentaje de piezas está asociado a necrópolis o conserva inscripciones votivas y, en cambio, su emplazamiento parece bien planificado, delimitando áreas explotables como pastos. Aceptando que el ganado sería propiedad sólo de determinados grupos sociales, estas piezas habrían sido colocadas para demarcar el control de un determinado territorio y, en definitiva, simbolizarían la riqueza en un entorno básicamente ganadero.

Al margen de su posible significación, nos parece interesante su distribución geográfica, pues completa casi toda la Meseta Occidental si la añadimos a la de las fíbulas, broches y demás figuritas anteriormente descritas. Ya Blanco (1988: 69 y ss.) señaló la coincidencia del reparto de los verracos y las fíbulas zoomorfas, aceptando su procedencia del mundo «hallstáttico». Su máxima concentración (Fig. 9) viene a coincidir con el territorio ocupado por los vettones, algunas de cuyas ciudades importantes fueron Salmantica o Abela (Ávila).

López Monteagudo (1989: 47) catalogó 280 piezas que identificó como: 144 toros, 128 verracos y ocho ejemplares de dudosa adscripción. Las figuraciones de cerdos o jabalíes son las que 


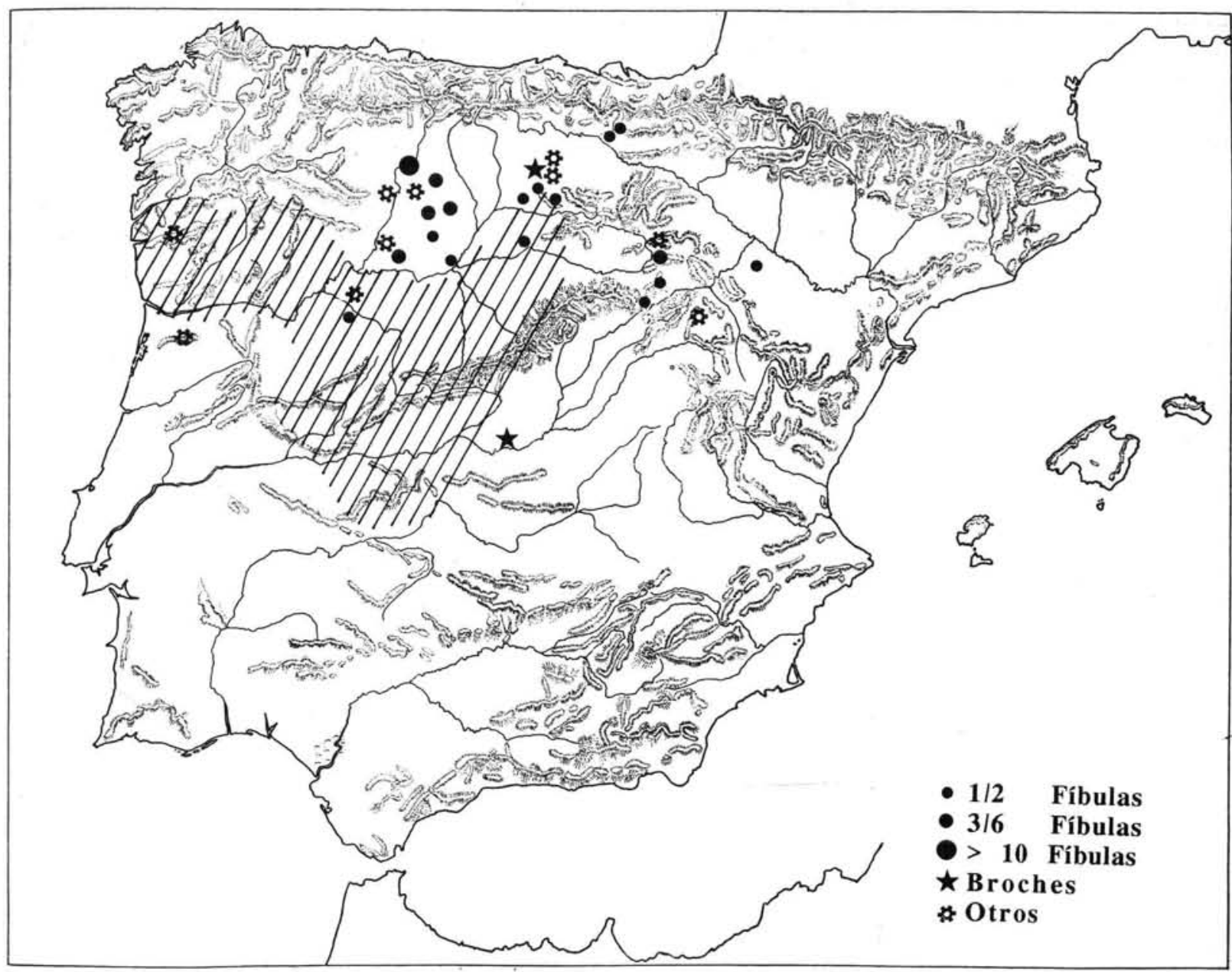

Fig. 9. Distribución geográfica de las diferentes representaciones de jabalí del área céltica meseteña. Zona rayada: dispersión verracos, según López Monteagudo (1989).

mejor tienen representada su anatomía, frente a los rasgos más diluidos de los toros.

Varios autores han relacionado las representaciones de Suidos con Marte y, por ejemplo, Acevedo (1982: 324) considera que una de las metamorfosis de esta divinidad, con el propósito de matar a Adonos, sería la de jabalí, basándose sobre todo en una inscripción hallada en Tuy en la que se puede leer «A Marte, en la forma divina de jabalí».

Tras esta rápida descripción de las diferentes imágenes de jabalí y observando el gráfico y su mapa de dispersión, comprobamos una especial concentración en las provincias noroccidentales. Las regiones meseteñas son las que con mayor propiedad podemos calificar de «célticas» sobre todo si consideramos este término desde el punto de vista lingüístico aunque no debemos olvidar la región peninsular del Suroeste que, según los textos greco-latinos, fue ocupada por celtas, si bien se suele aceptar que esas gentes llegaron al territorio de la Beturia procedentes de Lusitania (Berrocal, 1993).

El término celta es complejo y ha llegado a significar cosas muy distintas por lo que, para evitar confusiones y establecimiento de paralelos a veces forzados, la tendencia de gran número de investigadores, sobre todo filólogos, es considerar el término celta desde el punto de vista de la lengua. Como ya hemos recordado en otras ocasiones (Cerdeño, 1991), uno de los puntos que aceptaba Pauli (1985: 26) para definir a los celtas era: «a Celt is one who speaks Celtic», aunque añadía que este presupuesto puede demostrarse claramente en los últimos 
períodos de su desarrollo pero con mayores dificultades en las etapas antiguas de las que no se conservan fuentes documentales.

Considerando estos argumentos, es interesante revisar los mapas lingüísticos peninsulares para confirmar que las regiones meseteñas en que ahora nos fijamos hablaron indudablemente lenguas indoeuropeas, presumiblemente celtas. Unterman (e.p.) acepta que, excepto en la franja costera mediterránea y andaluza, se utilizó alguna lengua indoeuropea con más de un dialecto, uno de los cuales sería el hablado en Celtiberia al que consideró una subfamilia celta.

Parecido mapa lingüístico presentan otros autores, como Mallory (1989: 95) quien opina que el celtíbero o hispanocelta es uno de los tres grandes grupos del Celta Continental. Villar (1991: 443) ha identificado en la Península tres lenguas indoeuropeas, siendo la mejor conocida la celta, cuyo principal territorio de expansión fue la Celtiberia y, por ende, los celtíberos serían los habitantes de Iberia que hablaban celta. Según estas hipótesis, la lengua o lenguas célticas peninsulares tuvieron su mayor expansión en los territorios del centro y del centrooeste, lo que no deja de ser significativo a la hora de intentar establecer el origen de dichos dialectos.

En los últimos años está siendo cada vez más valorada la vía atlántica como posible ruta de entrada de las lenguas celtas, incluso del tronco indoeuropeo en general. Nos parece interesante la propuesta de Ruiz-Gálvez (1991) al interpretar el indoeuropeo, esencialmente el lusitano, como una especie de lengua franca utilizada por las comunidades atlánticas. A pesar de que sus argumentos han sido rebatidos desde el punto de vista de los filólogos, creemos que no debe rechazarse precipitadamente esta interpretación.

La mayoría de los investigadores han centrado siempre sus estudios en los territorios peninsulares más occidentales, sobre todo el Noroeste, la zona portuguesa e incluso Extremadura, quedando siempre más desatendida la Meseta y, aunque la problemática de las mencionadas relaciones no debe simplificarse, sí queremos llamar la atención sobre algunas características culturales que parecen avalarlas.

La presencia constatada del jabalí, tan representativa de todo el mundo celta europeo, podría ser uno más de otra serie de paralelis- mos cuyo desarrollo debería ser tratado ampliamente; valga como ejemplo, el cierto parecido entre la rica decoración que ornamenta la mayoría de las piezas metálicas (vainas, empuñaduras, broches de cinturón, etc.) utilizadas por los grupos prerromanos del occidente de la Meseta, con las decoraciones sobrecargadas de los diferentes estilos del Arte Céltico.

\section{OTROS ÁMBITOS GEOGRÁFICOS PENINSULARES}

Fuera de los territorios del interior peninsular, a los que hemos considerado en la órbita celta, también existen representaciones de jabalí, pero en proporción ostensiblemente menor y respondiendo a la influencia de corrientes culturales llegadas por el Mediterráneo, donde este motivo también formó parte de numerosas iconografías.

- Figurita de jabalí de Riotinto (Huelva), paralelizada con algunas de la Grecia clásica de época orientalizante (Blanco, 1964: 339-343).

- Bien representativos de la cultura ibérica son los relieves del monumento funerario de Pozomoro (Albacete) (Almagro Gorbea, 1978: 264-266), uno de los cuales muestra un jabalí con claro sentido funerario y el otro un jabalí bifronte, ambos al modo de las luchas de monstruos mixtos de la mitología orientalizante.

- Entre las esculturas ibéricas zoomorfas en piedra podemos destacar el ejemplar, de influjos helenísticos, procedente de Cartima (Málaga) (Paris, 1903: 136; Chapa, 1985: 202) y el jabalí alado de Torelló (Menorca), vinculado también al gusto mediterráneo (García y Bellido, 1936: 41 y láms. XVI-XVII).

- En algunas cerámicas ibéricas ha aparecido el tema del jabalí, como en un vaso funerario de la necrópolis de Archena, donde se le representa en una escena de caza (Blázquez, 1977: 236). También orientalizante es la pátera de plata de Tivissa (Tarragona), con una escena en la que el protagonista es el jabalí (Blázquez, 1977: 221, 354).

- Son interesantes las fíbulas de plata con escenas venatorias procedentes del Alto Guadalquivir. Sobre sus puentes se representa la caza del jabalí por parte de un jinete, con ayuda de perros (Angoso y Cuadrado, 1981: 18-30). Una pertenece al tesorillo de Chiclana de Segura (Jaén), otra procede de Cañete de las To- 
rres (Córdoba), y otros dos ejemplares formaban parte del tesoro de Los Almadenes de Pozoblanco (Córdoba).

Los autores antes citados incluyen también en su estudio una fíbula procedente de la Muela de Taracena (Guadalajara) por ser casi idéntica a las dos primeras. Nosotros pensamos, por su evidente parentesco tipológico e iconográfico, que su presencia en la Meseta es fruto de las influencias llegadas a esta zona desde el sur. Dudamos, pues, que estas fíbulas sean un buen ejemplo del Arte Celta según la idea de Almagro y Lorrio (1992: 419 y 433), quienes las definen como la "mejor obra de orfebrería céltica», a pesar de relacionar la escena de caza con los relieves ibéricos de simbolismo funerario y valorar positivamente los elementos estilísticos y técnicos procedentes de las culturas del Mediterráneo.

- Otra pieza meridional es el bronce de Maquiz (Mengíbar, Jaén), con jabalíes enfrentados de marcado carácter funerario (Almagro Basch, 1979: 176-181).

- El carrito votivo de Mérida también representa la típica escena de la caza del jabalí. Su origen último ha sido muy discutido por ser difícil su interpretación y sus vías de llegada a la Península (Blázquez, 1955: 44; Cuadrado, 1953: 119).

- Por último, queremos mencionar algunos ejemplos procedentes del mundo romano peninsular: El Ara funeraria de Barcelona, con la caza de un jabalí (García y Bellido, 1949: 306 y 370) y el Acueducto de Segovia, con la representación de Hércules junto al jabalí de Erimanto en uno de sus sillares (Bosarte, 1802: 29).

También es destacable el bronce del Instituto Valencia de Don Juan sobre el que se disponen una serie de figuras animales, incluido un suido (Obermaier, 1921: 130). Esta escena podría ser una versión indígena de una suovetaurilia romana, sacrificio de varios animales ante los dioses, que podría tener raíces indoeuropeas. Otro ejemplo similar sería el del bronce de Soutello de Anoia (Guimarâes, Portugal) (Severo, 1903: 325-331).

\section{EL MUNDO CLÁSICO}

No podemos dejar de mencionar que en el mundo griego aparece el jabalí como protagonista de algunos de sus mitos más relevantes
(Noël, 1987). Baste recordar la leyenda del «Jabalí de Calidón», que narra cómo Diana envió contra esa ciudad de Etolia un fiero jabalí que con sus grandes dimensiones y enormes colmillos destrozaba inclemente los árboles y las cosechas. El héroe Meneagro, hijo de Eneas, convocó a numerosos reyes y héroes de toda Grecia para participar en su cacería que fue difícil y peligrosa hasta que, él mismo y Atalanta, consiguieron dar muerte al animal cuya cabeza y piel fueron consideradas como un trofeo.

Se trata de un antiguo mito local inspirado en las fuerzas de la naturaleza, en el que se valora que la verdadera amenaza de los jabalíes no es que ataquen al hombre, sino su rapidez y contundencia en destrozar cosechas y romper canales de regadío, que poco a poco fue aumentando su carga poética y dramática hasta llegar a convertirse en una leyenda panhelénica.

Otro de los mitos clásicos destacables sería el tercer trabajo de Hércules, que acorraló y capturó vivo al terrible Jabalí de Erimanto (Arcadia), que hacía enormes estragos en los sembrados de la región, historia que ha quedado reflejada incluso en la pintura de algunos vasos áticos.

Tanto este mito como el anterior está considerado de los más antiguos de Grecia, lo que hace pensar que hunden sus raíces en épocas muy anteriores al momento clásico y podrían remontarse incluso a la llegada de los pueblos continentales al comienzo del primer milenio.

Posteriormente, el mito del jabalí tuvo gran difusión en el mundo romano hasta el punto de que Augusto mandó trasladar a Roma los dientes y colmillos que estaban consagrados a Diana en el templo de Tegea, supuestamente pertenecientes al Jabalí de Calidón. Normalmente, tuvo una clara significación mortuoria y es frecuente encontrarlo en la iconografía funeraria, en relieves de tumbas y sarcófagos o en estatuillas exentas. Los ejemplos que de esta época se conservan en España ya han sido comentados en el apartado anterior.

\section{LA EUROPA CÉLTICA}

Es obligada la cita del mundo céltico europeo, aunque sea en forma de breve apunte, puesto que pensamos que las representaciones de jabalí meseteñas tiene en él su referente más próximo. En dicho contexto existen numerosos 
ejemplos no sólo en piezas zoomorfas, sino también en mitos y leyendas cuyo protagonista es el jabalí.

No podemos detenernos en la recopilación y descripción de todas ellas, por lo que sólo queremos recordar que las piezas arqueológicas son abundantes, bien en forma de figurillas o exvotos de bronce, de grabados sobre recipientes $\mathrm{u}$ otros objetos o, ya en los últimos tiempos, en el reverso de algunas monedas.

Las figurillas de bronce conservadas podrían ser exvotos puesto que no puede atribuírseles ni siquiera la función práctica de nuestras fíbulas. Su distribución geográfica es muy amplia, encontrándose en todo el territorio celta europeo, desde Escocia e Inglaterra (Green, 1992: 47, 90), pasando por Francia (Maier, 1991: 414), Austria (Bökönyi, 1991: 431, 433), Bulgaria (Frey y Szabo, 1991: 481) o Hungría (Szabo, 1992), hasta la misma Ucrania (Maier, 1991: 414) (Lám. I).

En las figurillas europeas se observan algunas diferencias estilísticas con respecto a las peninsulares pues si en estas últimas, sobre todo en las fíbulas zoomorfas, el rasgo elegido como identificador de la especie es el largo y elevado hocico, en aquéllas se destaca el rasgo distintivo de un dorsal exagerado, con las cerdas de encima del lomo muy señaladas mediante un festoneado o un calado. Este atributo plástico responde, al igual que en las peninsulares, a una característica de los jabalíes, que en cualquier ocasión de peligro o tensión erizan todo el pelamen de la parte superior del lomo.

Dicho motivo iconográfico se conservó hasta época romana según parecen atestiguarlo algunas monedas, que podemos ejemplificar en el denario de plata de La Villeneuve-le-Roi (Haute Marne) en cuyo reverso aparece un jabalí muy estilizado, con todos los rasgos distintivos de la especie (Duval, 1989: 116).

Aparte de las representaciones materiales, también existen leyendas y mitos celtas en los que aparece el jabalí como protagonista lo que parece lógico en un contexto en el que muchas deidades tuvieron una representación zoomorfa y algunos animales fueron sacralizados.

Es habitual que, tanto a los jabalíes como a las otras especies singulares, se les represente o mencione como anormalmente grandes y fuertes o como poseedores de poderes mágicos. Tal ocurre en el cuento irlandés «Mac Dáthór's Boar» (MacCulloch, 1992: 122), donde un extraordina-
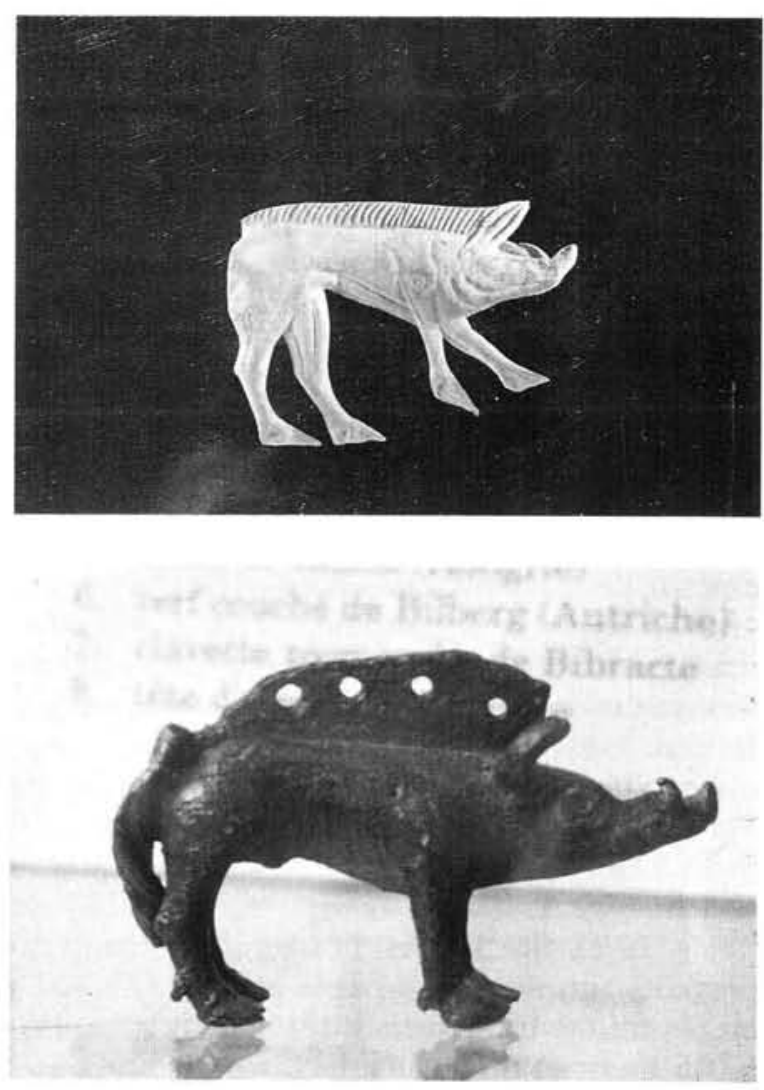

Lám. I. Figuritas de jabalí de Europa continental. 1: Región de Haute Marne, en piedra. 2: Bibracte (Borgoña), en bronce.

rio jabalí fue finalmente cazado por el nieto del rey y se necesitaron 60 bueyes para arrastrar su cuerpo; seguramente puede conmemorar una antigua fiesta ritual en honor de un animal al que se atribuían cualidades míticas.

Semejantes características contienen algunas leyendas galesas del ciclo artúrico, por ejemplo, la de «Culhwch y Olwen» en la que se habla de un enorme jabalí blanco, o en la de Pwyll que recibe como regalo del rey Arawn una piara de cerdos (Green, 1992: 169). Los cerdos y los jabalíes tuvieron un gran protagonismo en las viejas tradiciones de las Islas y siempre estaban presentes en las fiestas importantes o fueron considerados como seres del otro mundo (Green, 1992: 171).

En todas estas historias que narran cómo algunas divinidades o héroes cazaban jabalíes o cerdos fabulosos se observa una dualidad en dichos animales pue unas veces representan algún peligro o poder dañino para el entorno, o bien 
aparecen como los animales que eran sacrificados a la divinidad (MacCulloch, 1992: 126).

\section{SIGNIFICADO E INTERPRETACIÓN}

Tras este breve repaso a la mayoría de las figuraciones de jabalí del ámbito peninsular, parece evidente que esta especie animal fue, tras el caballo y quizás el toro, una de las más utilizadas selectivamente en la plástica e iconografía de los pueblos prerromanos.

Teniendo en cuenta la variedad de soportes utilizados para las representaciones de este motivo, así como sus diferentes lugares de utilización, hay que suponer que su finalidad y significación no fue idéntica en todos los casos. Es inevitable pensar que constituyeron un símbolo o encarnaron determinados conceptos, pero no siempre en la misma dirección. Hay que diferenciar en qué momento están resaltando el papel que jugaron en la economía doméstica y colectiva, y en consecuencia su repercusión social, y en qué otro responden a rituales funerarios o creencias religiosas, sin olvidar otras posibles interpretaciones.

En este último sentido, recordamos las apreciaciones de Galán (1989-90: 188) sobre las figurillas de arcilla encontradas en el castro celtibérico de Las Arribillas (Guadalajara), entre las que se encontraba un supuesto jabalí. Por proceder de un espacio doméstico y por la tosquedad de su ejecución, el citado autor deduce que se trata de objetos destinados al juego infantil más que de elementos simbólicos o sacralizados. Dada la naturaleza de esas piezas creemos acertada su interpretación pero destacamos su evidente diferencia, tanto en manufactura como en materia prima, respecto a la mayoría de los demás ejemplares mencionados.

En muchas ocasiones, los rasgos distintivos de la especie salvaje y de la doméstica son suficientemente expresivos pero hay ejemplos en los que podría dudarse entre la identificación del cerdo o del jabalí, que sí debieron tener un valor distinto entre aquellas gentes. Las descripciones, a veces fantásticas, que sobre estos animales dejaron los autores clásicos, el desconocimiento que tenemos de la exacta morfología del jabalí de la Edad del Hierro, por la escasez de restos en los yacimientos arqueológicos $(\mathrm{Me}-$ niel, 1987: 9), así como el menor tamaño de aquellos cerdos respecto a los actuales, han contribuido a la confusión entre ambos.

Desde el punto de vista económico es indudable que el cerdo jugó un papel destacado en la vida doméstica de las poblaciones antiguas e incluso hoy día lo sigue jugando en las economías rurales. Desde el Neolítico está documentada como una de las especies más productivas y tuvo una distribución geográfica extensa similar a la del jabalí, aunque no está demasiado claro su lugar de domesticación (Davis, 1989: 131).

Se les dedicó principalmente a la alimentación pues sus posibilidades de aprovechamiento son menores que en los bóvidos, utilizados también para la producción lechera y el transporte, pero su rendimiento es muy alto e incluso son útiles para la agricultura pues dejándoles hozar por los campos en primavera y otoño, remueven la tierra y la orean para la siguiente cosecha (Green, 1992: 18).

A través de los resultados obtenidos en algunos yacimientos franceses, se conocen las edades en que los cerdos eran sacrificados, entre uno y dos años una vez finalizado el período de crecimiento, y en general, los machos eran eliminados antes que las hembras debido en parte a que su agresividad aumenta con la edad (Meniel, 1987: 60). Por algunos instrumentos conservados y por los cortes y secciones que presentan los huesos y vértebras, se puede deducir la forma en que el cerdo era descuartizado, de manera similar a como se hace hoy día.

Los estudios faunísticos de diversos lugares latenienses indican que el cerdo ocupaba la segunda posición detrás de los bóvidos, pero se sitúa en el primer puesto si se atiende al número de individuos identificados (Meniel, 1987: $65,68)$. Por nuestra parte, la información que poseemos procedente de yacimientos celtibéricos, meseteños en general, es escasa y no permite ofrecer una valoración estadística completa. Podemos citar como ejemplo el poblado de La Coronilla (Guadalajara), ubicado en la Celtiberia oriental y excavado por uno de nosotros, donde el cerdo doméstico ocupa la tercera o cuarta posición, dependiendo de los niveles estratigráficos, con un NMI total de 40 individuos, casi todos ellos jóvenes, indicadores de un destino fundamentalmente alimenticio (Molero y cols., 1992: 109, 129; Sánchez y Cerdeño, 1992: 133-136).

Es evidente el gran valor que ha tenido el cerdo en las sociedades preindustriales e incluso 
hoy día, como recordaba A. Blanco (1983), el símbolo del ahorro doméstico sigue siendo una hucha en forma de cerdito. Este concepto del cerdo, del cochinillo, como animal beneficioso y productivo en los ambientes rurales debió encarnar también atributos divinos y es significativa su asociación a muchos santos católicos del centro y oeste de Europa, como San Martín, San Antón, San Blas, San Leonardo, patrón de la ganadería en Baviera y así hasta 61, relación que se considera muy antigua y producto de la cristianización de ancestrales prácticas de magia profiláctica (Blanco, 1983: 105-115).

A pesar de la indudable importancia económica que tuvo el cerdo, no cabe duda que fue el jabalí el animal que mayoritariamente aparece en la iconografía celta europea y celtibérica peninsular. Aunque también fuera aprovechado como alimento una vez cazado, no debió jugar un papel fundamental en la dieta, según los indicios conservados, por lo que aceptamos que las figuraciones que conocemos representaban determinados atributos o símbolos religioso-funerarios o rituales.

De los ejemplos mencionados en el texto, excluyendo los verracos, solamente dos parecen cerdos (espada de la figura 8 y quizás la fíbula de la figura 2,1) siendo jabalíes los restantes, con casi total seguridad. Pensamos que las esculturas de verracos son un caso especial por su tamaño, materia prima y lugar de ubicación y ya hemos comentado, líneas atrás, que algunos autores se inclinan por una interpretación socioeconómica más que por su tradicional consideración funeraria o mágica.

Entre las figuritas de bronce destacan numéricamente las fíbulas que eran objetos que cumplían una función práctica, aunque ello no impide pensar que la adopción de determinadas figuras zoomorfas encerrase un significado especial.

El hecho de que estas piezas sean encontradas normalmente entre los ajuares funerarios podría ser una prueba de ello, sobre todo si recordamos el ejemplo de las armas cuyo tratamiento ritual, antes de ser depositadas en las tumbas, indica algo más que su mera función práctica; en el caso de las fíbulas quizás sea una hipótesis aventurada ya que en las necrópolis se encuentran todos los modelos y no sólo los que poseen figuraciones de animales.

Independientemente del lugar de aparición de las piezas, que en muchos casos es muy signi- ficativo, está demostrado que en el mundo celta algunos animales fueron sacralizados, reverenciados y admirados por sus particulares cualidades (Green, 1989: 131-132) e incluso que ciertas deidades tomaron su forma, como por ejemplo Epona, la diosa-caballo, o Arduinna, la diosajabalí, a pesar de la aversión existente entre los celtas a la plasmación icónica de la divinidad (Marco Simón, 1987: 59).

Algunos animales ocuparon un lugar relevante en la imaginería religiosa, tanto como sacrificio a los dioses, caso del cerdo o del lechón, como por ser considerados la encarnación de ciertos principios, lo que conllevaba la exageración de determinadas partes de su cuerpo (Green, 1992: 218), por ejemplo, el prominente hocico en las representaciones celtibéricas o las cerdas dorsales erizadas de las figuritas europeas.

En general, las creencias religiosas de los celtas estuvieron estrechamente vinculadas al mundo natural en todas sus manifestaciones, en una constante interacción con la naturaleza que poseía poderes especiales (Green, 1989: 131 y 1992: 1), lo que motivó que muchos de sus cultos y rituales girasen en torno a ciertos animales, árboles, montañas o ríos.

En este sentido, recordamos los interesantes, aunque discutibles, puntos de vista de los sociobiólogos que consideran la religiosidad como algo innato, como una tendencia intrínseca, profundamente vinculada al entorno natural donde los animales juegan un papel importante que puede explicar por qué el hombre les atribuye capacidad para inspirar miedo y los adopta como símbolos de sus seculares y profundas emociones religiosas, independientemente de su ferocidad o no (Mundkur, 1988: 142).

A partir de estudios realizados desde la psicología y la biología sobre la emoción en relación con los cultos animales, aceptan que la sensibilidad psicológica hacia ciertos estímulos del entorno es innata y por ello provoca miedos y ansiedades y la atribución de extrañas cualidades a determinados animales. Esto no ocurre sólo en sociedades primitivas, sino también en otras épocas (animales fantásticos de la iconografía medieval) y en la actualidad, como puede observarse en las encuestas realizadas a escolares americanos que denotan un excesivo temor a algunos animales, especialmente salvajes, que acaban estando presentes hasta en sus sueños (Mudkur, 1988: 146, 157). 
Por su parte Douglas (1990: 25-36), en uno de sus recientes trabajos sobre el simbolismo animal, cree que la incorporación de animales a las categorías sociales humanas es una simple extensión de los principios que sirven para organizar las relaciones humanas; idea más cercana a algunos antropólogos estructurales que, ya desde Durkheim, consideraban la religiosidad como un reflejo ilusorio de lo social.

Además de las figuras de jabalí, aisladas o formando parte de algún otro objeto, típicas del mundo celta y celtibérico, es frecuente que aparezca en escenas de caza, actividad que debió practicarse con asiduidad dado que es una especie prolífica y, por ello, abundante. Su condición de animal nocturno, su costumbre de hozar en la tierra y las dificultades que conlleva su captura sólo con armas arrojadizas, propiciaron su vinculación al mundo misterioso y subterráneo y, de hecho, estuvo asociado al dios Endovélico, considerado una deidad infernal (Blázquez, 1977).

Las escenas de la caza fantástica del jabalí fueron comunes en todos los pueblos del mundo antiguo, especialmente en la cuenca mediterránea, y siempre tuvieron un sentido funerario, representando la victoria del héroe sobre el mal y la muerte, idea que según el profesor Blázquez (1977) pervivió en el folklore europeo hasta época medieval.

Esta relación del jabalí con el mundo de ultratumba está atestiguada no sólo en el mundo greco-etrusco sino también en el mundo celta y celtibérico, donde podrían ser un buen ejemplo las fíbulas zoomorfas que tienen entre sus patas $o$ en el extremo del hocico una pequeña cabeza humana. Es bien sabido que el rito de las «cabezas cortadas» o «cabezas trofeo» fue practicado entre los pueblos celtas que consideraban la cabeza como centro del ser humano y, por ello, poseedora de propiedades mágicas, aun después de la muerte del cuerpo. Este sentido funerario del jabalí también puede deducirse de su presencia en estelas de piedras donde aparece acompañado de numerosos signos de carácter astral.

Todas estas creencias harían que la caza del jabalí gozara de cierto prestigio y la consagración como cazador debió formar parte de determinados ritos iniciáticos que incluso hoy día podemos rastrear en algunas actitudes festivas. Por ejemplo, en la región de los Montes de Toledo, donde todavía existen numerosos jaba- líes (1), pervive una costumbre que viene a ser el bautizo de un cazador; cuando éste ha cobrado su primera pieza, los compañeros cogen al animal, lo abren en canal, sacan las vísceras y colocan el cárcavo sobre el nuevo cazador, sobre el que chorrea la sangre quien, ya iniciado en las lides cazadoras, invita a beber a todo el grupo. Esta costumbre y otras similares demuestran la singularidad que todavía tiene la caza de esta especie entre los aficionados a la caza mayor.

En resumen y al margen de estos ejemplos actuales, hemos visto a lo largo de este trabajo que la imagen del jabalí, tanto en escenas de caza como, sobre todo, aislada fue un motivo habitual en la plástica de los pueblos prerromanos del interior de la Península. Su distribución geográfica, coincidente con los territorios occidentales en los que se habló una lengua celta, así como los contextos arqueológicos de los que proceden sugieren una serie de vinculaciones culturales que no hemos hecho más que esbozar en las líneas precedentes.

\section{BIBLIOGRAFÍA}

Aguilera y Gamboa, E. (1916): Las necrópolis ibéricas. Asociación Española para el Progreso de las Ciencias. Madrid.

Almagro Basch, M. (1979): «Los orígenes de la toréutica ibérica». Trabajos de Prehistoria, 36: 176-211. Madrid.

Almagro Gorbea, M. (1978): «Los relieves mitológicos orientalizantes de Pozomoro (Albacete, España)». Trabajos de Prehistoria, 35: 251-278. Madrid.

Almagro Gorbea, M. y Lorrio, A. (1992): «Representaciones humanas en el Arte Céltico de la Península Ibérica». 2. Symposium de Arqueología Soriana (Soria, 1989): 410-540. Diputación Provincial. Soria.

Álvarez Ossorio, F. (1941): Museo Arqueológico Nacional. Catálogo de exvotos de bronce ibéricos. Madrid.

Álvarez SANChIS, J. (1990): «Los verracos del valle del Amblés (Ávila): del análisis espacial a la interpretación socio-económica». Trabajos de Prehistoria, 47: 201-233. Madrid.

ANGoso, C. y CuAdrado, E. (1981): «Fíbulas ibéricas con escenas venatorias». Boletín de la Asociación Española de Amigos de la Arqueología, 13: 18-30. Madrid.

ARGENTE, J.L. (1986-87): «Hacia una clasificación tipológica y cronológica de las fíbulas de la Edad del Hierro

(1) Agradecemos a d. J.A. García Castro la información proporcionada sobre la caza del jabalí. 
en la Meseta». Zephyrus, XXXIX-XL: 139-157. Salamanca.

ACEVEDO, R. (1982): «O porco na zoolatria ibérica». Sociedade Portuguesa de Antropología y Etnología, 24, 2: 321-327. Oporto.

BENOIT, F. (1954): «Monstres hippophores mediterranéens et "cavalier à l'Anguipéde" gallo-romains". Ogam, VI5: 219-226. Rennes.

Berrocal, L. (1993): «Los pueblos célticos del Suroeste de la Península Ibérica». Complutum, extra 2. Universidad Complutense, Madrid.

Blanco, A. (1964): «A caça e seus deusses na proto-historia peninsular". Revista de Guimarâes, LXXIV: 329348.

- (1983): «Cultura y simbolismo del cerdo». Historia, 16, 81: 105-115. Madrid.

- (1988): «Las estatuas de verracos y las fíbulas zoomorfas celtibéricas». Espacio, tiempo y forma, serie II, 1: 69-78. Homenaje al profesor Ripoll. UNED. Madrid.

Blánquez, J. y Álvaro, E. (1983): Los iberos. Catálogo de la Exposición. Ministerio de Cultura. Madrid.

Blázouez, J.M. (1955): «Los carros votivos de Mérida y Almorchón. Su significación religiosa». Zephyrus, VI: 41-60. Salamanca.

- (1977): «Imagen y mito. Estudio sobre religiones mediterráneas e ibéricas». Cristiandad. Madrid.

BöKÖNYI, S. (1991): «L'Allevamento». En S. Moscati (coor.): «I Celtiv: 429-435. Bompiani. Milano.

BOSARTE, D. (1802): Viaje artístico. Madrid.

CABRE, J. (1928): «Decoraciones hispánicas». Archivo Español de Arte y Arqueología, IV: 97-110. Madrid.

- (1937): «Broches de cinturón damasquinados con oro y plata». Archivo Español de Arte y Arqueología, 38: 93126. Madrid.

CAPRILE, P. (1986): «Estudio de los objetos de adorno del Bronce Final y Edad del Hierro en la provincia de Álava». Estudios de Arqueología Alavesa, 14. 416 pp. Vitoria.

CERDEÑo, Ma'L. (1986): «Tres fíbulas zoomorfas del Museo Lázaro Galdiano», Revista Goya, 193-195: 40-45. Madrid.

- (1991): «Necrópolis célticas, celtibéricas e ibéricas: una visión de conjunto». Congreso de Arqueología Ibérica. Las necrópolis: 473-508. Universidad Autónoma. Madrid.

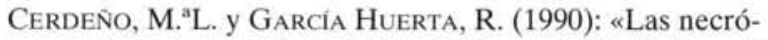
polis incineración del alto Jalón y el alto Tajo». II Symposium sobre Los Celtíberos (Daroca, 1988): 7592. Zaragoza.

Cuadrado, E. (1945): «El carro ibérico». III Congreso Nacional de Arqueologia: 116-135. Zaragoza.

ChapA, T. (1984): «Aspectos metodológicos de la tipología arqueológica: un ejemplo referido a las fíbulas de $\mathrm{La}$ Tène». I Jornadas de Metodología de la Investigación Prehistórica (Soria, 1981): 253-268. Ministerio de Cultura. Madrid.

- (1985): «La escultura ibérica zoomorfa». Ministerio de Cultura. Madrid.

Domingo, L. (1982): «Los materiales de la necrópolis de Almaluez (Soria) conservados en el Museo Arqueoló- gico Nacional». Trabajos de Prehistoria, 39: 241-278. Madrid.

Douglas, M. (1990): «The pangolin revisited: a new aproach to animal symbolism». En R. Willis (ed.): «Signifying animals. Human meaning in the natural world». 25-36. Unwin Hyman. London.

Duval, A. (1989): "L'Art Celtique de la Gaule". Editions de la Reunion des Musées Nationaux. Paris.

FREY, O.H. y SZABO, M. (1991): «I Celti nell'area Balcanica». En S. Moscati (coord.): «I Celti»: 478-484. Bompiani. Milano.

GALÁN, E. (1989-90): «Naturaleza y cultura en el mundo celtibérico». Kalathos, 9-10: 175-204. Teruel.

GARCì y BeLlido, A. (1949): «Esculturas romanas de España y Portugal». C.S.I.C. Madrid.

GreEn, M. (1989): «Symbol and Image in Celtic Religious Art». Routledge. London-New York.

- (1992): "Animals in Celtic Life and Myth". Routledge. London-New York.

Hernández Hernández, F. (1982): «Escultura zoomorfa del Occidente Peninsular». Trabajos de Prehistoria, 39: 211-239. Madrid.

López Monteagudo, G. (1989): «Esculturas zoomorfas celtas en la Península Ibérica». Anejos de Archivo Español de Arqueología, X. Madrid.

LUENGO, J.M. (1933-35): «Las fíbulas celtibéricas con jinetes y caballos de la provincia de León». Anuario de Prehistoria Madrileña, IV-V-VI: 191-195. Madrid.

Mac Culloch, A. (1992): «Celtic Mythology». Constable. London (1 1918$)$.

MaIER, F. (1991): «Gli oppida celtici (II-I a. J.C.)». En S. Moscati (coor.): «I Celti»: 411-426. Bompiani. Milano.

MALLORY, J.P. (1989): In search of the Indo-European. Thames-Hudson. London.

MARCo Simón, F. (1987): «La religión de los celtíberos», I Symposium sobre los Celtíberos (Daroca, 1986): 55-74. Zaragoza.

- (1991): «Mundo religioso y funerario». En "Los Celtas en la Peninsula Ibérica». Revista de Arqueología: 92. 101. Madrid.

Martin VALls, R. (1983): «Las insculturas del castro salmantino de Yecla de Yeltes y sus relaciones con los petroglifos gallegos». Zephyrus, XXXVI: 277-321. Salamanca.

Meniel, P. (1987): «Chasse et élevage chez les Gaulois (450-52 av. J.C.)». Errance, Paris.

Molero, G.; Brea, P. y Bustos, V. (1992): «Estudio de la fauna del yacimiento de La Coronilla. Campañas 198085». En M. ${ }^{a}$ L. Cerdeño y R. García Huerta: El castro de La Coronilla (Chera, Guadalajara). 1980-1986. Excavaciones Arqueológicas en España, 163. Madrid.

Morán, C. (1923-24): «Excavaciones arqueológicas en el cerro del Berrueco». Junta Superior de Excavaciones y Antigüedades, 65. Madrid.

- (1938): "Colección salmantina de fíbulas». Revista de Guimarâes, XLVIII: 111-136. Guimarâes.

Moran CABRÉ, J.A. (1975): «Sobre el carácter votivo y apotropaico de los broches de cinturón de la Edad del Hierro peninsular». XIII Congreso Nacional de Arqueología (Huelva, 1973): 597-603. Zaragoza. 
MOURE, J.A. y ORTEGA, L. (1981): «Fíbulas con esquema de La Tène procedentes de Paredes de Nava (Palencia)». Numantia, 1: 133-146. Soria.

MUNDKUR, B. (1988): «Human animality, the mental imagery of fear, and religiosity». En T. Ingold (ed.): «What is an animal?»: 141-185. Unwin Hyman, London.

NOEL, J.F.M. (1987): "Diccionario de mitología universal». Edicomunicación. Barcelona (edición facsímil).

OBermaier, H. (1921): «Bronce ibérico representando un sacrificion. Boletin de la Sociedad Española de excursiones, año XXIX 130-142. Madrid.

Pauli, L. (1985): «Early Celtic Society: two centuries of wealth and turmoil in Central Europe». En T. Champion y J. V. S. Megaw (eds.): «Settlement and Society. Aspects of West European Prehistory in the first millenium B.C.»:23-43. St. Martins Press. London.

PARIS, P. (1903): «Essai sur l'art et l'industrie de Espagne primitive». Paris.

Ruiz GÁlvez, M. (1991): «Songs of wayfaring lad. Late Bronze Age Atlantic exchange and the building of the regional identity in the west Iberian Peninsula». $O x$ ford Journal of Archaeology, 10-3: 277-306.

SACRISTÁn, J.D. (1986): «La Edad del Hierro en el valle medio del Duero. Rauda (Roa, Burgos)». Valladolid.

Sánchez, B. y CeRdeño, E. (1992): «La fauna del yacimiento de La Coronilla (Gadalajara). Campaña 1986». En M. ${ }^{2}$ L. Cerdeño y R. García Huerta: El castro de $\mathrm{La}$
Coronilla (Chera, Guadalajara). 1980-1986. Excavaciones Arqueológicas en España, 163. Madrid.

SCHÜLE, W. (1969): Die Meseta kulturen der Iberischen Halbinsel. Madrider Forschungen. Berlin.

SEVERO, R. (1899-1903): «Exvoto de bronce de colleçao Manoel Negrâo». Portugalia, I-2: 325-331. Porto.

Sopeña, G. (1987): «Dioses, ética y ritos. Aproximación para una comprensión de la religiosidad de los pueblos celtíberos». Inst. Fernando El Católico. Zaragoza.

SPERBER, D. (1978): "El simbolismo en general". Promoción Cultural S.A. Barcelona.

Szabo, M. (1992): «Les Celtes de l'Est: la seconde âge du fer dans la cuvette des Karpates». Errance, Paris.

Tovar, A. (1948): «El bronce de Luzaga y las téseras de hospitalidad latinas y celtibéricas". Emerita, 16: 75-91. Madrid.

UNTERMAN, J. (e.p.): «Lengua y poblamiento prerromano en el territorio celtibérico». III Symposium sobre Los Celtíberos (Daroca. Octubre, 1991).

VILLAR, F. (1991): "Los indoeuropeos y los orígenes de Europa. Lenguaje e Historia". Gredos. Madrid.

WATTENBERG, F. (1959): La región vaccea. Celtiberismo y romanización en la cuenca media del Duero. Bibliotheca Praeshistorica Hispanica, II. Madrid.

- (1963): Las cerámicas indigenas de Numancia. Bibliotheca Praehistorica Hispanica, IV. Madrid. 